\title{
The Increase in Learning Outcomes of Elementary School Mathematics Through Problem-Based Learning
}

\author{
Ririn Robayani ${ }^{1 *}$, Edy Bambang Irawan ${ }^{1}$, Bill Atweh $^{2}$
}

${ }^{\mathrm{I}}$ Graduate Program of Elementary Education, Universitas Negeri Malang, Malang, Indonesia.

${ }^{2}$ Science and Mathematics Education Centre, Curtin University of Technology, Perth, Australia.

\begin{tabular}{l|l}
\hline \multicolumn{1}{c|}{ A R T I C LE I N F O } & \multicolumn{1}{c}{ A B S T R A C T } \\
\hline $\begin{array}{l}\text { Received: 09-03-20I7 } \\
\text { Revised: 08-05-2017 } \\
\text { Accepted: 07-06-20I7 }\end{array}$ & $\begin{array}{l}\text { The aims of the research is to improve learning outcomes of mathematics through } \\
\text { problem-based learning. Classroom action research applied which was conducted in } \\
\text { two cycles. Results showed that problem-based learning could improve learning } \\
\text { outcomes of elementary school mathematics. The implementation of learning was } \\
\text { performed well that can be seen from the results of cycle I and cycle II which has } \\
\text { Keywords: }\end{array}$ \\
\cline { 2 - 2 } $\begin{array}{l}\text { Problem-Based Learning, } \\
\text { Learning Outcomes, } \\
\text { Mathematics }\end{array}$ & $\begin{array}{l}\text { C 2017 The Authors. Journal of K6, Education, and Management (j-K6EM). ISSN: 2580-2135. } \\
\text { Published by Graduated Program of Educational Management, Universitas Lambung } \\
\text { Mangkurat, Banjarmasin, Indonesia. This is an open access article under the open journal } \\
\text { systems 3. }\end{array}$ \\
\hline
\end{tabular}

*Author correspondence: Ririn Robayani; E-mail: rincurin69@gmail.com 


\section{Introduction}

As a process, education means all actions influencing the change of character, personality, thought, and behavior. This is in line with Mulyadi (2016) who states that learning process is teachers and students' activities in learning new knowledge, then the learners develop the new knowledge. Mathematics contains a lot of learning concepts that need to be understood properly.

A variety of subjects are taught in Elementary School, one of them is mathematics. This is in line with Ningrum (2016), she states that Mathematics is a science that is always used in everyday life, so that mathematics is taught since the elementary education level. According to Sa'dijah (2013), mathematics Learning in school has an important role to make students think logically and creatively in solving problems and making decisions.

The effect of good learning results is generated by good learning as well (Indrastuti, 2017). This is in accordance with Hedyanti (2016) who states that the benchmark of learning outcomes is used to determine the objectives of education. According to Amanah (2016), if the planning needed to solve the problem cannot last long in the memory of students, it will affect the problem-solving process.

Based on the observation results, most elementary school students have not been able to apply mathematical concepts yet in their everyday life. The problem is due to the low learning outcomes in mathematics in Elementary School. According to Maharani (2016) suggesting that one of the most important learning elements in the classroom is teacher actions. Teacher should control the situation of the class, so that it can create fun learning atmosphere as well as in accordance with the characteristics of the learners.

The way to overcome the problems occurred is to conduct classroom action research. The selected model should be able to make the students could solve problems in everyday life. Therefore, the suitable model to overcome the learning problems of Mathematics in 4th grade at Public Elementary School of Sungai Jingah 4, is
Problem-Based Learning. Problem-Based Learning is a learning model that is designed and developed to improve the ability of learners to solve problems (Riyanto, 20I4). The teacher plays a real problem, encourages, motivates, and provides teaching materials and facilities that the learners need to solve the problem.

Problem-Based Learning Model emphasis more on the learning process so the teacher should lead the students to develop the critical thinking skill. Students are also provided the opportunity to express their opinions and present the results obtained. In addition, the Problem-Based Learning can engage students actively to identify problem and propose the alternatives solution (Akbar, 2016). Arends (2004) identifies 5 stages of problem-based learning procedure, namely: I. Problem orientation, 2. Organize learners into learning condition, 3. Problem investigation, 4. Develop and present the investigation results, and 5. Evaluate and analyze the results of the problem solving (Riyanto, 20I4).

\section{Methodology}

A good methodology should bring the researcher to achieve of the objective (Dalle, 2010; Dalle et al., 2017; Derlina et al., 2018). The research used qualitative research as the method, in which the researchers collaborated with homeroom teachers to identify the problems that occurs in the learning process, and then find the alternative solution together. The type of research used was classroom action research. Classroom action Research was conducted through a process of looking back at the people involved and performed in a social situation including education, as well as aiming to improve various aspects (Wiguna, 2016).

The process of learning problems collection in the classroom was through self-reflection to solve the problem by performing many actions which are set in a real situation and analyzing every treatment effect (Sanjaya, 2010: 26). Classroom action research also has a characteristic of quality improvement of the process and the learning outcomes, the problem studied is practical, the main focus of research is the learning process, the responsibility for the implementation and the 
results of the classroom action research is the responsibility of the teachers as practitioners and implemented in accordance with applicable learning program (Sanjaya, 2010).

This research was conducted in the academic year 2016/2017 subject was 4th grade students at Public Elementary School of Sungai Jingah 4 Banjarmasin with number of male students as many as I3 male students and I6 female students. The subject used as research material was Mathematics with the material of area of two-dimensional figures. Data collection used in this research was students learning outcomes. If the assessment of analysis results on students' activities observation sheets indicated the percentage of $\geq 84 \%$, then it was categorized as very active criteria. To determine the improvement of student learning outcomes in each final test cycle in classical if it achieved $\geq$ $80 \%$ of all students, it achieved the minimum mastery criteria 70 .

\section{Results and Discussion}

The learning implementation by using ProblemBased Learning was performed in two cycles. Each cycle consisted of two meetings. The final cycle test was performed at the last meeting to determine the extent of students understanding toward the material delivered by the teacher. Analysis of the student learning outcomes in cycle I based on the analysis of the Cycle I is $75.86 \%$. While for the Cycle II of $88.89 \%$. From the results obtained in the cycle II, it has achieved the predetermined criteria of $\geq 80 \%$.

On the planning stage, the teachers prepare the learning tools and material in form of student observation sheet and student competency test. This is in line with Irawan (2016) who states that learning process of mathematics designed by the teachers to change the learning activities cannot be performed directly. So, in the early stages, teachers should design the learning process at the first place.

At the stage of implementation and observation, teachers implement the syntax of Problem-Based Learning followed by the observation process. Teacher activities can be seen from the observation sheet containing some aspects of Problem-Based Learning implementation, namely the Problem orientation, organize the learners into the learning condition, problems investigation, develop and present the investigation results, as well as evaluate and analyze the results of the problem solving. At the stage of problems orientation, it is good for the teachers to introduce the problems associated with everyday life to the learners.

This is in line with Herman in Choridah (2013) stating that the problem-based Learning is cooperative learning, so that students will discover and comprehend the difficult concepts easier if they can discuss these issues with their peers. The teacher can give the students the opportunity to express their opinion, hear their friends' opinion, and discuss the problems provided by the teacher together. By applying cooperative learning, it is expected to provide contribution toward communication skills and creativity in solving mathematical problems.

At the stage of student orientation, it consists of 3 steps, namely (I) performing apperception; (2) motivating students by providing problem; and (3) conveying the objectives and steps of the learning activities. In organizing the learners, teachers should create interactive atmosphere and give the chance to students to get involved. In addition, teachers are quite good in guiding the students to investigate the problem provided. Teacher facilitated the students in developing and presenting the investigation results during the learning activities. At the stage of evaluating the problem, teacher performed good in guiding the students in analyzing the results of problem solving. This is in accordance with Uno \& Mohamad (2012), they state that problem-based learning is a learning method using authentic problem as the source of learning, so that students are trained to think critically and develop their personality through problems in everyday life.

The data of students learning outcomes were obtained from evaluation tests conducted at the end of each meeting with the aim to measure the competence of the students in mastering the material provided and also final evaluation at the end of cycle including learning materials from all meetings in the cycles.

Based on the results of the evaluation test performed on cycle I and cycle II, the average value of student learning outcomes has increased. 
On the evaluation of cycle, I of classical mastery was 75.86 and in cycle II of classical mastery was $88.89 \%$. The improvement of learning outcomes in cycle II was inseparable from the teacher and student activity. The teacher activity increased due to the effectiveness of time management, so that any learning activity that students do can be more optimal and students' activity was increased. With the increase of student activity, it can improve student learning outcomes. This is in line with Johnson \& Johnson in Trianto (2010) who state that the purpose of cooperative learning is to maximize student learning process to improve academic achievement and both individual and group understanding.

\section{Conclussion and Recomendations}

Based on the results of the analysis and discussion, it can be concluded that problembased learning on the material of area of twodimensional figures at the 4th grade elementary school can improve student learning outcomes. It can be seen from the indicators of students in reviewing the problems, investigating the problems, developing and presenting results of the investigation, and evaluating as well as analyzing the results of the problem. The implementation of learning performed well, judging from the results of cycle I of $75.86 \%$. While for the second cycle is $88.89 \%$, which achieved the predetermined criteria of $\geq 80 \%$.

\section{Acknowledgment}

No acknowledgment

\section{References}

Akbar, T. (2016). Penerapan pemebelajaran berbasis masalah degan memanfaatkan lingkungan untuk meningkatkan kemampuan berpikir kritis kelas 7e smpn 24 banjarmasin. Prosiding Seminar Nasional Pendidikan Dasar, Malang. 470-484.

Choridah, D.T. (2013). Peran pembelajaran berbasis masalah untuk meningkatan kemampuan komunikasi dan berpikir kreatif serta disposisi matematis siswa sma. Infinity Journal. 2(2), I94202
Dalle, J. (20I0). Metodologi umum penyelidikan reka bentuk bertokok penilaian dalaman dan luaran: Kajian kes sistem pendaftaran siswa Indonesia. Thesis PhD Universiti Utara Malaysia.

Dalle, J., Hadi, S., Baharuddin., \& Hayati, N. (2017). The Development of Interactive Multimedia Learning Pyramid and Prism for Junior High School Using Macromedia Authorware. The Turkish Online Journal of Educational Technology, November. 7I4-72I.

Derlina., Dalle, J., Hadi, S., Mutalib, A.A., \& Sumantri, C. (2018). Signaling Principles in Interactive Learning Media through Expert's Walkthrough. Turkish Online Journal of Distance Education (TOJDE). I9(4), I47-I62

Irawan, E. B. (2016). The challenge of elementary mathematics teachers in dealing with various curriculum changes (a theoretical review). Prosiding Seminar Nasional Pendidikan Dasar. Malang,I-6.

Maharani, L. T. (20I6). Metode penemuan terbimbing dengan scarffolding pada pembelajaran matematika sd. Prosiding Seminar Nasional Pendidikan Dasar, Malang. 249-257.

Mulyadi, A. (2016). Pembelajaran kooperatif tipe stad dengan joyful learning di sekolah dasar. Prosiding Seminar Nasional Pendidikan Dasar. Malang. 230238.

Ningrum, I. P. (2016). Implementasi pembelajaran realistic mathematic education pada materi skala di sekolah dasar. Prosiding Seminar Nasional Pendidikan Dasar 2016, 647-655.

Riyanto, Y. (2014). Paradigma baru pembelajaran sebagai referensi bagi pendidik dalam implementasi pembelajaran yang efektif dan berkualitas. Jakarta: Kencana.

Sa'dijah, C. (2013). Kepekaan bilangan siswa smp melalui pembelajaran matematika kontekstual yang mengintegrasikan keterampilan berpikir kreatif. Jurnal Pendidikan dan Pembelajaran (JPP). 20(2), 222-227.

Sanjaya, W. (2010). Stategi pembelajaran berorientasi standar proses pendidikan. Jakarta: Kencana.

Trianto. (20II). Model-model pembelajaran inovatif beroientasi konstruktivistik. Jakarta: Prestasi Pustaka.

Uno, H. B. \& Muhammad, N. (2012). Belajar dengan pendekatan pailkem: pembelajaran aktif, inovatif, lingkungan, kreatif, efektif, menarik. Jakarta: Bumi Aksara. 